\title{
PROFESIONALISME GURU IPS SMP KABUPATEN SLEMAN YOGYAKARTA
}

\author{
Nasiwan, Agustina Tri Wijayanti, Sudrajat \\ Jurusan Pendidikan IPS FIS Universitas Negeri Yogyakarta \\ Email: sudrajat@uny.ac.id, agustina_tw@uny.ac.id
}

\begin{abstract}
Abstrak
Penelitian ini bertujuan untuk mendapatkan hasil tentang tingkat profesionalisme guru IPS SMP di Kabupaten Sleman. Penelitian menggunakan metode penelitian survai yaitu jenis penelitian yang mengumpulkan informasi tentang karakteristik, tindakan, pendapat dari sekelompok responden yang representative yang dianggap sebagai populasi. Desain survai yang dipilih adalah cross-sectional dimana desain survai dilakukan terhadap sampel tertentu dalam jangka waktu yang relatif pendek. Populasi penelitian adalah guru IPS SMP/Mts di Kabupaten Sleman yang berjumlah 239 orang yang mengajar pada sekolah swasta maupun negeri. Dengan teknik simple random sampling tim peneliti mengambil sampel sebanyak 41 responden. Teknik pengumpulan data menggunakan kuesioner (angket) yang terdiri dari 32 item pertanyaan. Teknik analisis data yang dipergunakan statistik diskriptif dengan menghitung mean, modus dan median untuk menemukan dan menggambarkan tendensi sentral profesionalisme guru IPS di Kabupaten Sleman. Hasil penelitian menunjukkan bahwa profesionalisme guru IPS SMP/Mts di Kabupaten Sleman belum baik (memuaskan). Dari lima aspek yang disurvai, hanya dua aspek yang menunjukkan baik, sedangkan empat aspek lainnya hanya bisa dikatakan cukup. Keempat aspek yang disurvai yaitu: kemampuan akademik $(2,55)$, kemampuan guru dalam penelitian dan karya ilmiah $(2,43)$, kemampuan dalam pengembangan profesi (2,93), wawasan kependidikan guru $(2,93)$. Satu aspek lainnya yang disurvai adalah motivasi dan dorongan untuk berprestasi yaitu 2,94.
\end{abstract}

Kata Kunci: Profesionalisme, Guru IPS, Motivasi Berprestasi. 
Nasiwan, Agustina Tri Wijayanti, Sudrajat|

\begin{abstract}
This study aims to obtain results about the level of professionalism of SMP teachers in Sleman. The research used survey research method that is the type of research that collects information about the characteristics, actions, opinions of a group of representative respondents who are considered as population. The design of the selected survey was cross-sectional in which the survey design was conducted on a particular sample in a relatively short period of time. The population of this research is the IPS teachers of SMP/Mts in Sleman, amounting to 239 people teaching in private and public schools. With simple random sampling technique, the research team took 41 respondents. Data collection techniques used questionnaires consisting of 32 question items. Data analysis techniques used descriptive statistics by calculating mean, mode and median to find and describe the central tendency of IPS teacher professionalism in Sleman. The results showed that the professionalism of IPS SMP teachers in Sleman District has not been good (satisfactory). Of the five aspects surveyed, only two aspects indicate good, while the other four aspects can only be said enough. The four aspects surveyed are: academic ability (2.55), teacher ability in research and scientific work (2,43), ability in professional development (2,93), teacher education insight (2,93). One other aspect surveyed was motivation and encouragement for achievement of 2.94 .
\end{abstract}

\title{
Keywords: Professionalism, Teachers, Achievement Motivation.
}

\section{Pendahuluan}

Pendidikan merupakan faktor terpenting dalam upaya meningkat-kan kesejahteraan, kemajuan, dan kualitas hidup. Pengalaman negara-negara tetangga, misalnya Korea Selatan, Jepang, Singapura, dan Malaysia menunjukkan bahwa kemajuan besar dalam semua bidang kehidupan yang dicapainya didorong oleh kualitas pendidikannya yang semakin baik. UU No. 20 tahun 2003 menyatakan bahwa pendidikan merupakan usaha agar 
manusia dapat mengembangkan potensi dirinya melalui proses pembelajaran atau cara lain yang dikenal dan diakui oleh masyarakat. Pendidikan merupakan salah satu langkah strategis untuk mencetak anak-anak Indonesia menjadi generasi penerus bangsa yang berkualitas.

Pendidikan seharusnya menyentuh seluruh dimensi kehidupan manusia baik intelektual, psikomotorik, emosional, serta moral. Pengem-bangan manusia seutuhnya sebagaimana dimaksud dalam tujuan pembangunan nasional Indonesia, seharusnya lebih meng-utamakan terbentuknya kepribadian yang mandiri dan kreatif disertai tanggung jawab moral dan sosial yang tinggi. Perkembangan kehidupan yang semakin kompleks terutama pada era globalisasi seperti sekarang ini menuntut paradigma baru pendidikan yang menekankan pada pengembangan manusia yang dapat beradaptasi terhadap perubahan, kreatif serta dapat memecahkan permasalahan kehidupan yang semakin kompleks secara mandiri.

Pendidikan tidak dapat dilepaskan dengan upaya otonomisasi atau pembebasan serta pembentukan pola berpikir kritis sebagai penyiapan generasi muda untuk menjadi warga masyarakat. Otonomisasi dan pembentukan pola berfikir kritis merupa-kan salah satu pilar civil society yang hanya dapat diwujudkan melalui pendidikan. Dewasa ini pendidikan nasional Indonesia dihadapkan pada empat krisis pokok yakni: kuantitas, relevansi atau efisiensi eksternal, elitisme, dan manajemen. Tilaar (2008) menyatakan bahwa ada tujuh masalah pokok dalam sistem pendidikan nasional, yaitu: menurunnya akhlak dan moral peserta didik; pemerataan kesempatan belajar; masih rendahnya efisiensi internal sistem pendidikan; status kelembagaan, manajemen 
Nasiwan, Agustina Tri Wijayanti, Sudrajat

pendidikan yang tidak sejalan dengan pembangunan nasional; sumber daya manusia yang belum profesional.

Pendidikan merupakan wahana sosialisasi dan transmisi warisan budaya bangsa, nilai-nilai kebudayaan nasional, dan nilai-nilai lain yang dituntut oleh masyarakat global. Pendidikan juga belum berhasil mengembangkan insan pembangunan yang mampu mengolah dan mengelola sumber daya alam, mengelola modal, mengembangkan teknologi, menghasilkan komoditas yang mutunya mampu bersaing dan mampu mengembangkan sistem perdagangan. Pendidikan nasional belum sepenuhnya mampu mengembangkan manusia Indonesia yang religius, intelektual, berakhlak, berwatak ksatria, serta berjiwa patriotik sehingga tantangan dunia pendidikan semakin berat memasuki abad XXI.

Permasalahan penting yang berkaitan dengan kualitas pendidikan adalah kualitas guru yang masih rendah. Ketersediaan pendidik belum mencukupi baik secara kualitas maupun kuantitas, kesejahteraan pendidik masih rendah, dan biaya operasional pendidikan dan fasilitas belum memadai. Berbagai kebijakan yang diterapkan pemerintah dalam rangka meningkatkan profesionalitas guru bertujuan untuk lebih meningkatkan kualitas pendidikan secara nasional. Upaya tersebut harus diseimbangkan dengan kesiapan guru untuk berkarya dan bekerja lebih baik lagi dan terbuka terhadap perubahan yang harus mereka lakukan. Suatu keharusan bagi guru professional untuk selalu melakukan usaha dan upaya untuk meningkatkan kualitasnya sehingga memenuhi kompetensi guru profesional.

Untuk meningkatkan kualitas pendidikan, sudah seharusnya dilaksanakan upaya peningkatan professionalisme guru, karena ia merupakan faktor yang amat menentukan kualitas 
pendidikan. Guru berperan sebagai pendidik profesional dengan tugas utama mendidik, mengajar, membimbing, mengarahkan, melatih, menilai dan mengevaluasi peserta didik pada pendidikan dasar dan menengah. Sebagai pendidik profesional, guru bukan saja dituntut melaksanakan tugasnya secara profesional, tetapi juga harus memiliki pengetahuan dan kemampuan profesional. Salah satu cara yang dapat dilaksanakan adalah dengan memetakan profesionalisme guru-guru baik dari sekolah dasar hingga sekolah menengah sehingga peran guru dalam membawa kemajuan bangsa dapat berjalan dengan efektif dan tepat sasaran.

Peningkatan profesionalisme guru diharapkan dapat melahirkan profil guru Indonesia yang professional, dimana setiap guru memiliki kepribadian yang matang, menguasai ilmu pengetahuan dan teknologi, memiliki keterampilan untuk membangkitkan minat peserta didik pada sains/teknologi, serta mampu melakukan pengembangan profesi secara berkesinambungan. Untuk mengantisipasi tantangan dalam dunia pendidikan yang semakin global, maka profesionalisme guru harus terus ditingkatkan. Beberapa upaya telah dilakukan untuk mengatasi kurangnya kemampuan guru, misalnya dengan pendidikan dan latihan (diklat), workshop, dan sebagainya. Namun upaya tesebut belum mampu meningkatkan profesionalisme guru secara signifikan. Mentalitas dan spirit guru menjadi faktor penting bagi upaya membangun guru yang profesional. Motivasi yang tinggi utuk selalu berkarya dan berkembang merupakan syarat mutlak yang harus ditumbuhkembangkan di kalangan guru. Dengan adanya motivasi untuk berkembang dan maju diharapkan guru dengan kesadaran sendiri melakukan upaya-upaya peningkatan profesionalismenya. 
Nasiwan, Agustina Tri Wijayanti, Sudrajat

Guru IPS SMP di Kabupaten Sleman, Yogyakarta harus meningkatkan motivasi untuk berkembang, maju, dan serta profesionalismenya. Hal ini tidak berlebihan mengingat Sleman sebagai salah satu barometer kemajuan pendidikan harus selalu meningkatkan kualitas pendidikannya dengan memberdayakan dan mengelola guru-gurunya dengan benar. Kegiatan MGMP harus direformasi agar dapat berkembang menjadi forum ilmiah untuk melakukan kajian, kegiatan diseminasi, atau workshop yang bermuara pada peningkatan kualitas dan profesionalisme guru IPS. Di samping itu pemerintah (dinas pendidikan) perlu memberikan dukungan agar MGMP dapat berkembang menjadi forum akademik yang produktif dan berkualitas. Untuk itu perlu program-program yang nyata dan berkesinambungan sehingga profesionalisme guru IPS dapat terus berkembang.

\section{Pendidikan dan Pembangunan Bangsa}

Pendidikan merupakan investasi penting dalam menghadapi masa depan dunia secara global. Untuk itu, pendidikan harus dapat menyiapkan generasi muda abad ke-21 yang unggul, berdaya saing tinggi dan mampu bekerjasama guna mencapai kemakmuran bagi setiap negara dan dunia. Namun, Pembangunan tidak akan bisa tumbuh dengan baik walaupun peningkatan mutu pendidikan atau mutu sumber daya manusia dilakukan, jika tidak ada program yang jelas tentang peningkatan mutu pendidikan dan program ekonomi yang jelas.

Mengingat pentingnya peran pendidikan tersebut, maka investasi modal manusia melalui pendidikan di negara berkembang sangat diperlukan walaupun investasi di bidang pendidikan merupakan investasi jangka panjang secara makro, manfaat dari investasi ini baru dapat dirasakan setelah puluhan 
tahun. Keterbatasan dana mengharuskan adanya penetapan prioritas dari berbagai pilihan kegiatan investasi di bidang pendidikan yang sesuai, dalam jangka panjang akan mendorong laju pertumbuhan ekonomi. Investasi yang menguntungkan adalah investasi modal manusia untuk mempersiapkan kreativitas, produktivitas dan jiwa kompetitif dalam masyarakatnya.

Dalam pengertian yang sederhana pendidikan diartikan sebagai usaha manusia untuk membina kepribadiannya sesuai dengan nilai-nilai di dalam masyarakat dan kebudayaannya. Dalam perkembangannya istilah pendidikan berarti bimbingan atau pertolongan yang diberikan dengan sengaja oleh orang dewasa agar ia menjadi dewasa. Langeveld (Hasbullah, 1999: 2) menyatakan bahwa pendidikan ialah setiap usaha, pengaruh, perlindungan dan bantuan yang diberikan kepada anak tertuju kepada pendewasaan anak itu, atau lebih tepat membantu anak agar cukup cakap melaksanakan tugas hidupnya sendiri. Pengaruh itu datangnya dari orang dewasa atau yang diciptakan oleh orang dewasa seperti buku, sekolah dan ditujukan kepada orang yang belum dewasa. Sementara itu Driyarkara (1980: 128) menyebutkan bahwa pendidikan adalah pemanusiaan manusia muda ke dalam alam nilai-nilai dan kebudayaan sehingga menjadi manusia yang sempurna. Sedangkan KH Dewantara menyatakan bahwa pendidikan adalah tuntunan di dalam hidup tumbuhnya anak-anak. Maksud dari pernyataan tersebut adalah menuntun segala kekuatan kodrat pada anak-anak itu agar mereka menjadi manusia dan sebagai anggota masyarakat dapat mencapai keselamatan dan kebahagiaan yang setinggi-tingginya (Hasbullah, 1999: 4). 
Nasiwan, Agustina Tri Wijayanti, Sudrajat

Pada dasarnya pendidikan diselenggarakan dalam rangka membebas-kan manusia dari berbagai persoalan hidup yang melingkupinya. Bagi Paulo Freire (Firdaus M Yunus, 2007: 1) pendidikan merupakan salah satu upaya untuk mengembalikan fungsi manusia menjadi manusia agar terhindar dari berbagai bentuk penindasan, kebodohan sampai kepada ketertinggalan. Oleh karenanya, manusia sebagai pusat pendidikan harus menjadikan pendidikan sebagai alat pembebasan untuk mengantarkan manusia menjadi makhluk yang bermartabat. Dalam proses ini pendidikan dimaknai sebagai proses pembentukan kepribadian dan pengembangan seseorang sebagai makhluk individu, sosial, susila, dan makhluk yang beragama. Kesemuanya menghendaki manusia menjadi makhluk yang seimbang sehingga diharapkan pendidikan dapat menyediakan proses untuk mencapai tujuan tersebut.

John Dewey (Ornstein \& Levis, 1989: 139) mengemukakan bahwa education is that reconstruction or reorganization of experience and which increases ability to direct the course of subsequent experience. Dalam kalimat tersebut terkandung pengertian bahwa pendidikan merupakan rekonstruksi dari pengalaman-pengalaman yang secara langsung meningkatkan kemampuan seseorang dalam menghadapi pengalaman berikutnya. Dengan demikian pendidikan harus diarahkan pada upaya untuk membangun kemampuan kognitif serta kematangan emosional peserta didik sehingga ia dapat memecahkan permasalahan yang semakin kompleks.

Herbart (McNergney \& Herbert, 2001: 42) yang menyatakan bahwa ...primary goal of education was to respect a child's individuality while conveying the discipline and consistency necessary to develop moral strength of character. Jadi menurut 
Herbart tujuan utama pendidikan adalah menghormati individualitas anak di samping kebutuhan untuk menegakkan disiplin dan konsistensi untuk membangun kekuatan moralnya. Moralitas yang dibangun dalam pendidikan diharapkan dapat membekali peserta didik untuk terjun ke dalam kehidupan di masyarakat. Hal ini penting karena dalam situasi sekarang ini orang dihadapkan pada kehidupan yang semakin kompleks. Globalisasi, liberalisasi, dan menjamurnya media massa telah membuat orang cenderung memilih gaya hidup hedonistis yang mengabaikan nilai dan moralitas.

\section{Profesionalisme Guru IPS}

Guru adalah salah satu unsur penting yang harus ada sesudah siswa. Apabila seorang guru tidak punya sikap profesional maka murid yang dididik akan sulit untuk tumbuh dan berkembang dengan baik. Hal ini karena guru adalah salah satu tumpuan bagi negara dalam hal pendidikan. Dengan adanya guru yang profesional dan berkualitas maka akan mampu mencetak anak bangsa yang berkualitas pula. Kunci yang harus dimiliki oleh setiap pengajar adalah kompetensi. Kompetensi adalah seperangkat ilmu serta ketrampilan mengajar guru di dalam menjalankan tugas profesionalnya sebagai seorang guru sehingga tujuan dari pendidikan bisa dicapai dengan baik.

Guru sebagai sebuah profesi menuntut kualifikasi dan kompetensi tertentu yang hanya dapat diperoleh melalui sistem pendidikan yang khusus. Sardiman (2009: 133) berpendapat secara umum profesi diartikan sebagai suatu pekerjaan yang memerlukan pendidikan lanjut dalam science dan teknologi yang digunakan sebagai perangkat dasar untuk diimplementasikan dalam kegiatan yang bermanfaat. KBBI (2005: 897) menyebutkan 
Nasiwan, Agustina Tri Wijayanti, Sudrajat

kata profesi berarti bidang pekerjaan yang dilandasi pendidikan keahlian (keterampilan, kejuruan, dan sebagainya) tertentu.

Profesionalisme menekankan kepada penguasaan ilmu pengetahuan atau kemampuan manajemen beserta strategi penerapan-nya. Maister (1997) mengemukakan bahwa profesionalisme bukan sekedar pengetahuan teknologi dan manajemen tetapi lebih merupakan sikap, pengembangan profesionalisme lebih dari seorang teknisi bukan hanya memiliki ketrampilan tinggi tetapi memiliki tingkah laku yang dipersyaratkan. Arifin (2001) mengemukakan bahwa guru Indonesia yang professional dipersyaratkan mempunyai dasar ilmu yang kuat sebagai pengejawantahan terhadap masyarakat teknologi dan masyarakat ilmu pengetahuan, penguasaan kiat profesi berdasarkan riset dan praktis pendidikan yaitu ilmu pendidikan sebagai ilmu praksis bukan hanya merupakan konsepkonsep, pendidikan merupakan proses lapangan yang bersifat ilmiah serta pengembangan kemampuan professional berkesinambungan merupakan profesi yang berkembang terus menerus antara LPTK dengan praktek pendidikan.

Tugas guru secara professional adalah membantu peserta didik agar mampu melakukan adaptasi terhadap berbagai tantangan kehidupan serta desakan yang berkembang dalam dirinya. Pemberdayaan peserta didik meliputi aspek kepribadian terutama aspek intelektual, sosial, emosional dan ketrampilan. Dedi Supriadi (1998) mengatakan bahwa ada lima kompetensi yang harus dimiliki oleh guru yang professional, diantaranya adalah: 1) mempunyai komitmen yang tinggi kepada siswa serta proses belajarnya, 2) menguasai bahan ajar secara mendalam serta cara mengajarkannya sesuai dengan pengalaman siswanya, 3) bertanggung jawab melakukan dan menguasai berbagai teknik 
evaluasi, 4) mampu berfikir sistematik tentang apa yang dilakukan dan mampu belajar dari pengalaman serta 5) merupakan bagian dari masyarakat belajar dalam lingkungan profesinya. Kompetensi profesional merupakan kemampuan yang berkenaan dengan penguasaan materi pembelajaran bidang studi secara luas dan mendalam yang mencakup penguasaan substansi isi materi kurikulum mata pelajaran di sekolah dan substansi keilmuan yang menaungi materi kurikulum tersebut, serta menambah wawasan keilmuan sebagai guru. Kompetensi sosial berkenaan dengan kemampuan pendidik sebagai bagian dari masyarakat untuk berkomunikasi dan bergaul secara efektif dengan peserta didik, sesamapen-didik, tenaga kependidikan, orangtua/wali peserta didik, dan masyarakat sekitar.

UU No. 23 Tahun 2008 tentang Guru dan Dosen menjelaskan bahwa guru wajib memiliki kualifikasi akademik, kompetensi, sertifikat pendidikan, sehat jasmani dan rohani serta memiliki kemampuan untuk mewujudkan tujuan pendidikan nasional. Kemudian dalam pasal 9 dijelaskan bahwa kualifikasi dimaksud adalah guru wajib memiliki kualifikasi akademik melalui perguruan tinggi program sarjana atau diploma empat. Pada pasal 10 dijelaskan kompetensi guru dimaksud meliputi kompetensi paedagogik, kompetensi kepribadian, kompetensi sosial dan kompetensi profesional yang diperoleh melalui pendidikan profesi.

Dalam pengertian pendidikan profesionalisme guru secara luas mempunyai peran sebagai: (1) Konservator (pemelihara) sistem nilai yang merupakan sumber norma kedewasaan; (2) Inovator (pengembang) sistem nilai ilmu pengetahuan; (3) Transmitor (penerus) sistem-sistem nilai tersebut kepada peserta didik; (4) Transformator sistem-sistem nilai tersebut melalui 
Nasiwan, Agustina Tri Wijayanti, Sudrajat|

penjelmaan dalam pribadinya dan perilakunya, dalam proses interaksi dengan sasaran anak didik; (5) Organisator (penyelenggara) terciptanya proses edukatif yang dapat dipertanggung-jawabkan, baik secara formal (kepada pihak yang mengangkat dan menugaskannya) maupun secara moral. Penilaian terhadap profesi guru tidak hanya sekedar pada aspek kualitas, administrasi dan manajemen saja, tetapi masalah guru lebih luas dan kompleks, menyangkut kemampuan profesional, personal, sosial termasuk perilaku dan kurangnya penghargaan yang layak terhadap profesi guru. Goodlad (1984: 167) menyatakan:

It seems reasonable to expect the teacher to be a key factor in the schooling process; and indeed our data showed that student's perceptions of their teacher's interest in them as persons were related to their satisfaction in the classroom.

\section{Metode Penelitian}

Jenis penelitian yang dipilih yaitu penelitian survey yaitu: jenis penelitian yang mengumpulkan informasi tentang karakteristik, tindakan, pendapat dari sekelompok responden yang representative yang dianggap sebagai populasi (Masri Singarimbun \& Sofian Efendi, 1982: 8). Mc. Millan \& Schumacher (2001: 304) menyatakan:

In survey research, the investigator select a samples of respondents and administers a questionnares or conduct interview to collect informations on variables of interest. The data that are gathered are used to describe characteristic of certain population. Survey are used to learn about people's attitude, beliefs, values, demographics, behavior, opinions, habits, desires, ideas, and other types of informations.

Desain survai yang dipilih adalah cross-sectional dimana desain survai yang dilakukan terhadap sampel tertentu dalam jangka waktu yang relatif pendek. Data yang diperoleh dari 
penelitian cross-sectional biasanya tentatif karena variabel-variabel yang diteliti memang sifatnya berubah-ubah (alterable or changed variable).

Populasi penelitian adalah guru IPS SMP di Kabupaten Sleman Yogyakarta yang terdiri dari 232 orang tersebar di sekolah swasta maupun negeri. Dengan teknik simple random sampling terpilih 40 orang guru IPS yang tergabung dalam MGMP Guru IPS Kabupaten Sleman. Sedangkan teknik pengumpulan data menggunakan kuesioner yang terdiri dari 32 pertanyaan tertutup. Teknik analisis data yang dipergunakan adalah statistik diskriptif yaitu seluruh jawaban responden dikonversi menjadi empat kategori dengan rumus berikut:

\begin{tabular}{|c|c|c|}
\hline Rumus & Rerata Skor & Kategori \\
\hline $\begin{array}{l}\overline{X l}+0,60 \times S B i<X \leq \overline{X \imath}+1,80 \\
\text { SBi }\end{array}$ & $>3,4-4,2$ & Sangat Baik \\
\hline $\begin{array}{l}\overline{X l}-0,60 S B i<\quad X \quad \leq \overline{X l}+ \\
0,60 S B i\end{array}$ & $>2,6-3,4$ & Baik \\
\hline $\begin{aligned} \overline{X \imath}-1,80 S B i & <X \\
& \leq \overline{X \imath}-0,60 S B i\end{aligned}$ & $>1,8-2,6$ & Cukup \\
\hline $\mathrm{X} \leq \overline{X_{\imath}}-1,80 S B i$ & $\leq 1,8$ & Kurang \\
\hline
\end{tabular}

S. Eko Putro Widoyoko (2009: 238)

\section{Hasil Penelitian dan Pembahasan}

Guru IPS di Kabupaten Sleman yang bertugas di SMP baik negeri maupun swasta berjumlah 232 orang dengan status kepegawaian PNS maupun non PNS. Kebanyakan guru IPS SMP di Kabupaten Sleman sudah berstatus sebagai guru profesional (65\%) karena sudah memiliki sertifikat pendidik yang telah mereka peroleh melalui portofolio (15\%) dan sisanya diperoleh melalui jalur Pendidikan dan Latihan Profesi Guru (PLPG). Dengan demikian profesionalisme guru IPS SMP di Kabupaten Sleman 
Nasiwan, Agustina Tri Wijayanti, Sudrajat|

dianggap baik. Namun meskipun demikian, ketika bertugas di lapangan (sekolah) profesionalitas mereka kadang-kadang dipertanyakan oleh banyak pihak. Beberapa indikator menunjukkan bahwa guru IPS kurang profesional dalam berbagai aspek, misalnya hasil Uji Kompetensi Guru (UKG) yang masih tergolong rendah, hasil belajar siswa dalam mata pelajaran yang diampu juga belum memuaskan, serta minimnya inovasi dan kreasi yang dihasilkannya.

Gambar 2. Kompetensi Profesional dan Pedagogis Guru IPS

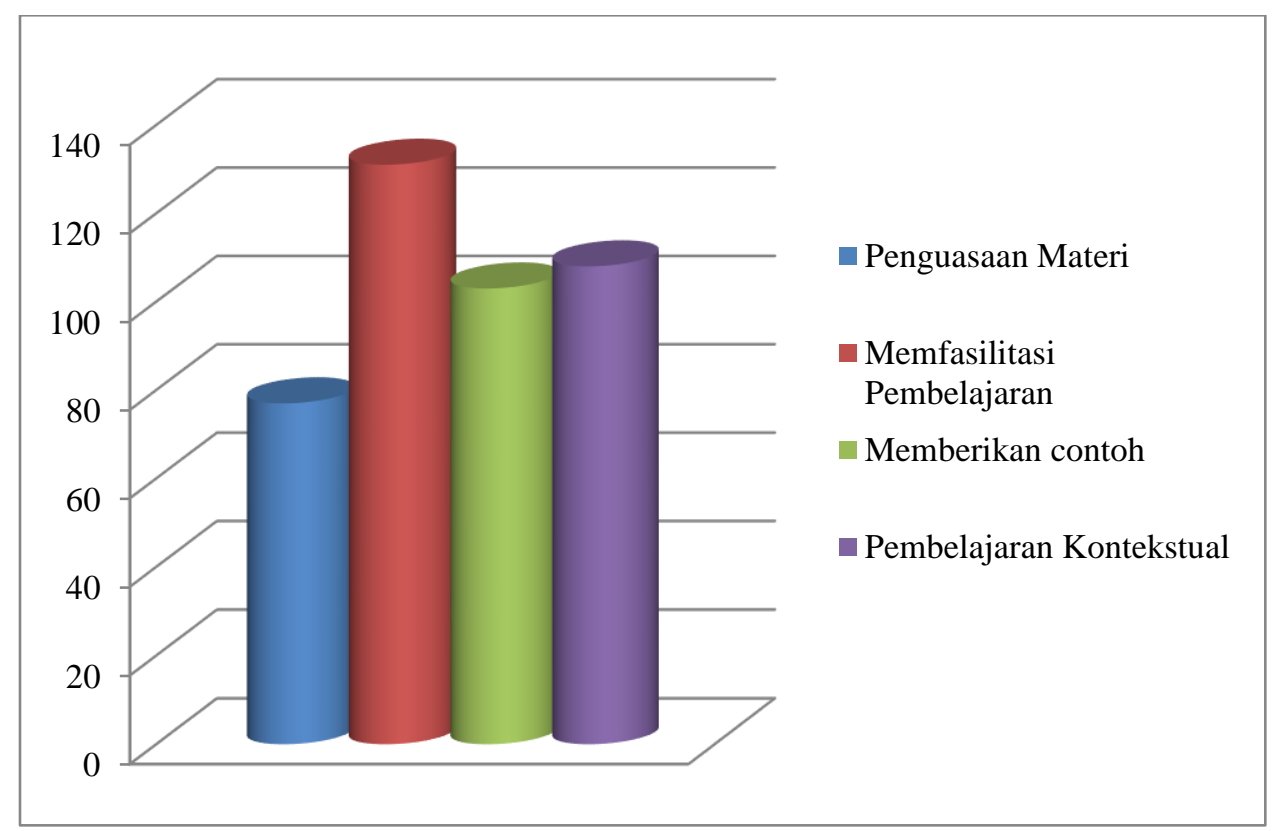

Sumber: Data primer yang diolah peneliti

Gambar 2. mengelaborasi kompetensi profesional dan pedagogis guru IPS di Kabupaten Sleman dimana penguasaan materi IPS mendapat skor 77, sedangkan kemampuan dalam melaksanakan pembelajaran mendapatkan skor 131, kemampuan untuk memberikan contoh-contoh 103, dan kemampuan dalam memfasilitasi pembelajaran kontekstual sebesar 108. Total skor yang diperoleh yaitu 419. Dengan menggunakan rumus yang telah ditetapkan, maka dapat diperoleh nilai sebesar 2,55 yang apabila 
dikonsultasikan dengan tabel maka hasil kuesioner untuk kategori tersebut dikatakan cukup.

Diagram di atas juga menunjukkan bahwa penguasaan materi IPS masih rendah, sedangkan kompetensi peda-gogisnya cukup. Apabila dikaitkan dengan hasil UKG yang masih rendah temuan tersebut menyediakan jawaban bahwa rendahnya hasil UKG disebabkan oleh rendahnya kemampuan guru dalam memahami dan menguasai materi IPS. Rendahnya kompetensi professional guru disebab-kan oleh rendahnya tingkat literasi guru dimana mereka enggan untuk mengupdate pengetahuan melalui kegiatan membaca dan mengikuti kegiatan ilmiah seperti seminar, konferensi, stadium general, dan lain-lain.

Sementara itu kompetensi pedagogis Guru IPS SMP Kabupaten Sleman cukup tinggi. Hal tersebut dapat dilihat dari kemampuan guru dalam memfasilitasi pembelajaran yang dikatakan baik. Guru juga telah terbiasa melaksanakan pembelajaran kontekstual, sebuah pendekatan pembelajaran yang relevan dengan konteks pembelajaran IPS. Kemam-puan tersebut berkorelasi positif dengan lamanya mengajar. Namun semakin bertambah lama, ternyata kemampuan profesionalnya ber-kurang secara signifikan.

Gambar 3. Kemampuan menghasilkan karya ilmiah 


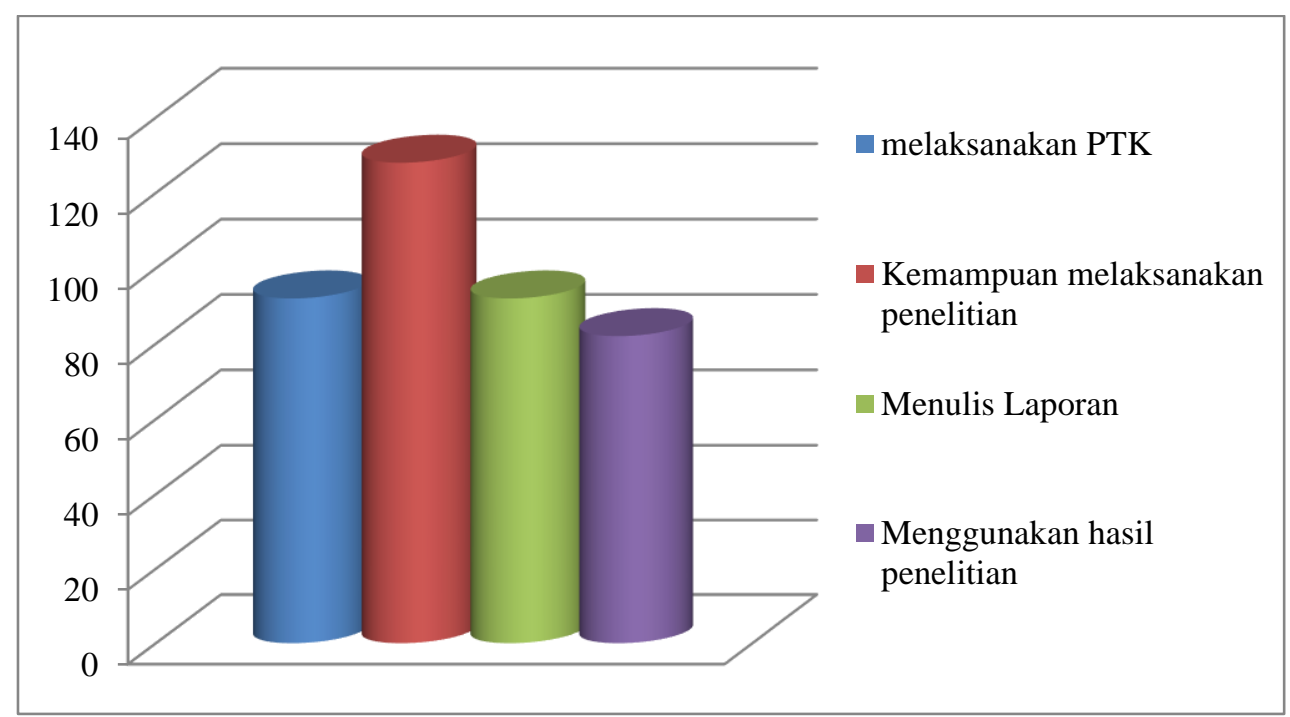

Sumber: Data primer yang diolah peneliti

Gambar 3 menunjukkan kemampuan guru IPS dalam melak-sanakan penelitian tindakan kelas (PTK) mendapatkan skor 92, kemam-puan melaksanakan penelitian mendapatkan skor 128, kemampuan menulis laporan penelitian mendapatkan skor 92, dan kemampuan untuk menggunakan penelitian dalam meningkatkan kualitas pembela-jaran mendapatkan skor 82, total skor yang diperoleh dalam aspek kedua yaitu: 394. Dikonsultasikan dengan rumus yang telah ditetapkan maka kategori kedua mendapat skor 2,43 atau berpredikat cukup.

Secara umum kompetensi guru dalam menghasilkan karya ilmiah khususnya penelitian tindakan kelas masih sangat memprihatinkan. Fakta bahwa banyak guru yang karir kepegawaiannya berhenti pada golongan IV A dan mengalami kesulitan untuk meningkatkan ke-pangkatannya ke jenjang IV B dan seterusnya yang disebabkan oleh persyaratan untuk menghasilkan karya ilmiah menjadi bukti serius dari persoalan tersebut. Guru mengalami masalah besar dalam penyusunan karya ilmiah disebabkan oleh beban mengajar 24 jam pelajaran 
seminggu serta persyaratan administratif lainnya. Namun persoalan sebenarnya adalah ketidaksiapan guru untuk terus memperkuat kompetensi profesionalnya melalui kegiatan update pengetahuan sehingga mereka tidak mempunyai ide yang dapat dijadikan bahan untuk penelitian.

Gambar 3. Pengembangan profesi

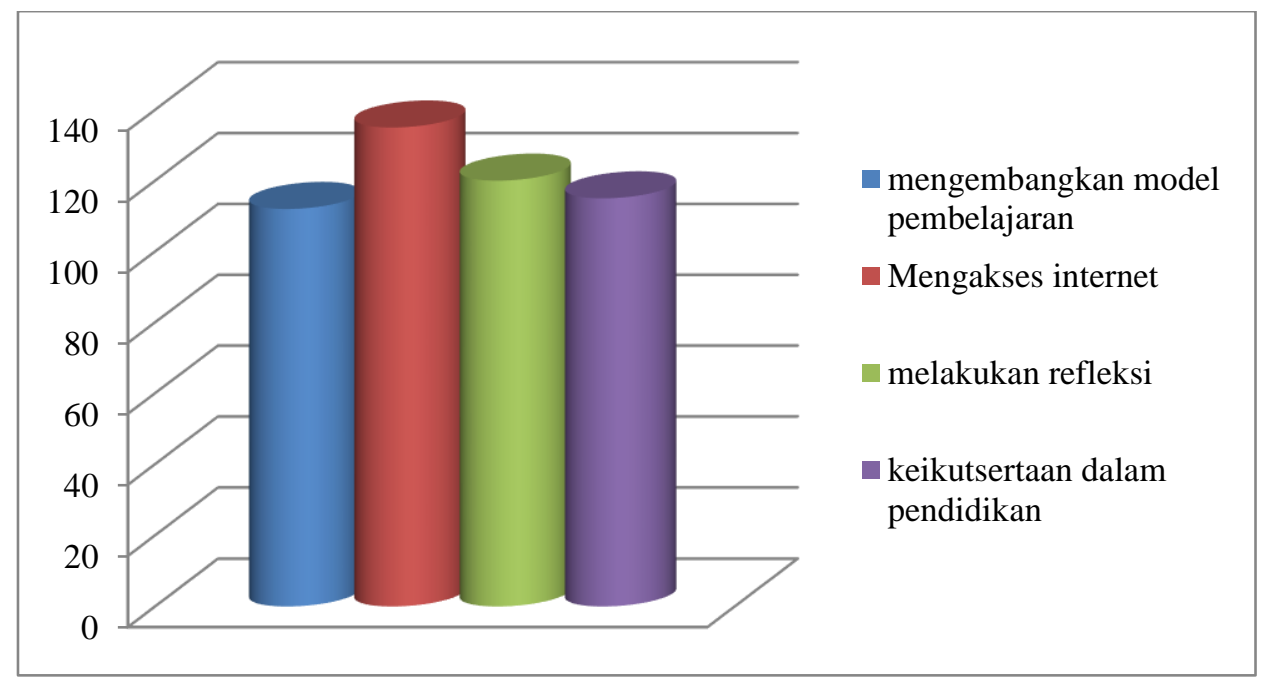

Sumber: Data primer yang diolah peneliti

Dari gambar 3 di atas terlihat bahwa beberapa kemampuan yang dimiliki oleh guru memiliki nilai sebagai berikut: mengembangkan model pembelajaran yang inovatif 112, kemampuan guru untuk mengakses internet mendapat skor 135, kemampuan melakukan refleksi terhadap kinerjanya secara kontinyu mendapat skor 120 dan keikutsertaan guru dalam kegiatan pendidikan dan pelatihan yang diselenggarakan oleh sekolah, atau MGMP mendapat skor 115. Dari penghitungan matematis maka aspek kemampuan mengembangkan profesinya mendapatkan skor 482 yang dikonversikan ke dalam rumus yang telah ditentukan mendapat skor 2,93 dikategorikan baik. Pengembangan profesi guru IPS IPS SMP di Kabupaten Sleman dapat dikategorikan baik disebabkan oleh lingkungan yang 
Nasiwan, Agustina Tri Wijayanti, Sudrajat

mendukung seperti dekatnya dengan lembaga pendidikan, tersedianya sarana dan prasarana pendidikan serta peran dinas pendidikan Sleman yang cukup maksimal. Minat guru IPS untuk mengikuti pendidikan pada jenjang yang lebih tinggi yaitu jenjang magister cukup tinggi.

Pasal 7 ayat 2 UU No 14 Tahun 2005 menyatakan bahwa pemberdayaan profesi guru atau pemberdayaan profesi dosen diselengga-rakan melalui pengembangan diri yang dilakukan secara demokratis, berkeadilan, tidak diskriminatif, dan berkelanjutan dengan menjunjung tinggi hak asasi manusia, nilai keagamaan, nilai kultural, kemajemukan bangsa, dan kode etik profesi. Pengembangan dan pemberdayaan profesi guru masih belum menyentuh akar permasalahan yang selama ini dihadapi yaitu menumbuhkembangkan konsep belajar sepanjang hayat (lifelong education) dalam diri guru sehingga semakin tinggi pangkatnya semakin meningkat profesionalisme. Lembaga Penjamin Mutu Pendidikan (LPMP) atau lembaga lainnya seakan tidak berdaya menghadapi persoalan tersebut. Oleh karenanya perlu dirumuskan konsep pemberdayaan dan pengembangan profesi guru secara menyeluruh yang melibatkan pihak-pihak yang berkompeten yaitu: LPMP, LPTK, dan pemerintah daerah.

\section{Simpulan}

Guru IPS di Kabupaten Sleman yang bertugas di SMP baik negeri maupun swasta berjumlah 232 orang dengan status kepegawaian PNS maupun non PNS. Kebanyakan guru IPS SMP di Kabupaten Sleman sudah berstatus sebagai guru profesional (65\%) karena mereka sudah memiliki sertifikat pendidik yang telah mereka peroleh melalui portofolio (15\%) dan sisanya diperoleh melalui jalur Pendidikan dan Latihan Profesi Guru (PLPG). Dengan 
demikian profesionalisme guru IPS bisa dikatakan sudah baik, meskipun di sekolah profesionalitas mereka kadang-kadang dipertanyakan oleh banyak pihak. Beberapa indikator menunjukkan bahwa guru IPS kurang profesional dalam berbagai aspek, misalnya hasil Uji Kompetensi Guru (UKG) yang masih tergolong rendah, hasil belajar siswa dalam mata pelajaran yang diampu juga belum memuaskan.

Hasil angket menunjukkan bahwa profesionalisme guru IPS SMP di Kabupaten Sleman belum memuaskan. Keempat aspek yang diteliti menunjukkan bahwa kinerja guru dalam penguasaan materi IPS masih dalam kategori cukup, membuktikan bahwa profesionalisme guru dalam menguasai materi pelajaran yang diampunya masih memprihatinkan. Tidak mengherankan apabila hasil Uji Kompetensi Guru masih belum memuaskan. Kompetensi pedagogisnya juga belum memuaskan karena kebanyakan guru menyatakan bahwa mereka belum mempraktikkan model-model pembelajaran secara bervariatif.

\section{Daftar Pustaka}

Arifin, I. (2001). Profesionalisme Guru: Analisis Wacana Reformasi pendidikan dalam Era Globalisasi. Makalah Disajikan dalam Simposium Nasional Pendidikan di Universitas Muhammadiyah Malang, 25-26 Juli 2001.

Badrun Kartowagiran. (2011). Kinerja Guru Profesional (Guru Pascasertifikasi). Cakrawala Pendidikan, XXX, 3, hlm. 463473.

Dedi Supriadi. (1998). Mengangkat Citra dan Martabat Guru. Yogyakarta: Adicita Karya Nusa.

Doni Koesoema (2007). Pendidikan Karakter, Strategi Mendidik Anak di Zaman Global. Jakarta: Grasindo. 
Nasiwan, Agustina Tri Wijayanti, Sudrajat

Driyarkara. (1980). Driyarkara Tentang Pendidikan. Yogyakarta: Kanisius.

Firdaus M Yunus. (2007). Pendidikan Berbasis Realitas Sosial: YB Mangunwijaya-Paulo Freire. Yogyakarta: Logung Pustaka.

Goodlad, J. (1984). A Place Called Scholl. New York: Mc Grow Hills.

Hasbullah. (1999). Dasar-dasar Pendidikan. Jakarta: Grasindo

Lewis, Catherine C. (2002). Lesson study: A Handbook of Teacher Instructional Change. Philadelphia, PA: Research for Better Schools, Inc.

Lilies Noorjannah (2014). Pengembangan Profesionalisme Guru Melalui Penulisan Karya Tulis Ilmiah Bagi Guru Profesional Di SMA Negeri 1 Kauman Kabupaten Tulungagung, Humanity, I, 2, hlm. 21-31.

Maister, DH. (1997). The True Professionalism. New York: The Free Press

Ornstein, Allan C. \& Levis, Daniel U., (1989). Foundation of Education. Boston: Houghton Mifflin Co.

Rachman Halim Yustiyawan (2014). Pengaruh Motivasi dan Kompetensi Profesional Guru Yang Bersertifikasi Terhadap Kinerja Guru Di SMP Negeri 1 Surabaya. Jurnal Inspirasi Manajemen Pendidikan, III,. 3, hlm. 114-123.

Robinson, Naomi. (2006). Lesson Study: An example of its adaptation to Israeli middleSchoolteachers.stwww.weizmann.ac.il/Gmath/ICMI/Robinson_proposal.doc

Sardiman (2009). Interaksi dan Motivasi Belajar Mengajar. Jakarta: Rajawali Press.

Sugiyono. (2008). Metode Penelitian Pendidikan: Pendekatan Kualitatif, Kuantitatif, dan $R \& D$. Bandung: Alfabeta.

Surya, Muhammad. (2003). Percikan Perjuangan Guru. Semarang: Aneka Ilmu. 
JIPSINDO No. 2, Volume 4, September 2017

Tilaar, HAR. (2008). Kebijakan Pendidikan. Yogyakarta: Pustaka Pelajar

Undang-undang Dasar RI Nomor 14 Tahun 2005 tentang Guru dan Dosen 